\title{
On Campus Technical Training Facilities in Media Schools of Lahore.
}

\author{
Hafiz Qasir Abbas ${ }^{1}$, Fatima Tuz Zohra ${ }^{2}$ \\ ${ }^{1}$ Lecturer at Government College University, Faisalabad \& M.Phil Fellow Department of Mass \\ Communication, Allama Iqbal Open University Islamabad. Model Town Link Road, Lahore, Pakistan. \\ ${ }^{2}$ Postgraduate Student of Institute of Communication Studies, University of the Punjab, Lahore. Mansoora \\ Multan Road, Lahore, Pakistan.
}

\begin{abstract}
Despite Pakistan's great geographic, cultural and demographic diversity, it shares many challenges and issues that are fundamental to improve the quality and relevance of media education as a means of human resources development and reliable source of information for ignorance stricken but an emerging nation. Educational institutes which are imparting media education must consider a coherent strategy for training of media students in which on campus training facility plays an important and vital role. Among the critical issues that must be considered when planning training programs to develop above mentioned resources are the following: Growing number of students in media schools and continuously increasing utilization of media by masses; poor offers of internships for fresh graduates at media houses and inefficiency of PEMRA in ensuring training facilities for students at these media houses; increasing demands for secondary and technical education; and poorly managed training infra structure at public sector media schools.

The success of on campus training of media students in any developing country can be considered a key indicator of the country's advancement in the field of media and it is sure to have well learned and seasoned journalist that can be given responsibility of information dissemination and social awareness. Any country that evolved into an advanced one in communication field, media training must have played an active and vital role as skilled manpower would have been required, also to enable its sustainability.

The choice of this paper title was done having carefully considered the following factors:

$>$ Pakistan has entered into an era of free media where information flow is very rapid and has been seen as the most actively participated activity, by workers and users.

$>$ Recent years' national political scenario has gone through a phase of transition from dictatorship to democracy which it largely owes to free media. It advocates need and utility of media for Pakistan.

> Geographic diversity, cultural \& ethnic diversity makes a lot of space for development through media which requires well trained media professionals.

> Community media has played an active role in disaster management, as in 2006 earth quake PUFM 104.6 played an active role, advocates need of more functional and active media training facilities.

This paper compares facilities available in media schools in order to know their current strength for producing highly motivated and learned media professionals. The survey research method has been employed to collect information of equipment and manpower available to these media training schools. By the end, the paper suggests ways to make things better by improving facilities for the students of media in order to have professional and trained work force for newly born media of Pakistan.
\end{abstract}

Key words; Pakistan, Education, Training, Media Schools, PUFM 104.6, Radio Kinnaird 96.6, Voice of LCWU 97.6, Political Change, awareness.

\section{Introduction}

PEMRA Act 2002 not only brought number of media channels but also bestowed them freedom of speech. It increased number of media users rapidly. This not only brought change in the outlook of media practices but also revolutionized media studies in the educational institutes of Pakistan. The new scenario demanded more learned and trained media professionals. Thus, forcing media schools to re-design their curriculum and provide more technical trainings to their students. Therefore, the researcher has taken an indepth survey of available media practice houses, (which are in radio form so far as no university has its television practice house) to find their technical strength in order to train their students for future challenges. The present study is based on three educational radios of Lahore which are as follows;

\subsection{Punjab University FM 104.6}

Punjab University has been running its own radio channel "Punjab University FM 104.6" (PUFM 104.6) since 2004. It is situated in the premises of Punjab University's Institute of Communication Studies. 
Institute of Communication studies manages all the affairs of the PUFM 104.6, including administration, programming, production, and presentation. PUFM 104.6 is the first ever educational radio channel in Punjab province of the Pakistan established in the universities. Pakistan Electronic Media Regulatory Authority (PEMRA) issued the license for PUFM 104.6 on the educational grounds as a result of its flexible policy for the promotion of electronic media. Punjab University FM 104.6 is basically a non- commercial radio channel which has been established for the training purposes of media students studying in Institute of communication studies, university of Punjab and provides educational information services to the people of in its surroundings. Students doing specialization in print \& electronic media practice their knowledge of practical journalism in a real encouraging Radio broadcasting atmosphere.

Punjab University FM 104.6 Radio station is fully equipped with latest and modern broadcasting facilities funded by UBESCO. The Station is located in the broadcasting wing of the Institute of Communication Studies, Punjab University.

Punjab University Radio FM 104.6 started its transmission on $5^{\text {th }}$ June, 2004 when the than Vice Chancellor Punjab University Bridg. Arshad Mahmood inaugurated the station. The transmission of PUFM 104.6 is aired for four hours daily from $2 \mathrm{pm}$ to $6 \mathrm{pm}$. The students of Institute of Communication Studies work in radio station as volunteer presenters, announcers, and script writer and programme researchers. This is all because of the dedication of the than station director Prof. Dr. Mughees-ud-Din Sheikh who devoted all his energy to make PUFM 104.6 a real training center for his students. The broadcasting and infrastructural facilities available in PUFM does not exist in the broadcasting houses of many universities of media studies across the world.

Punjab University radio has signed MOU's with many national and international broadcasting organizations. An MOU has recently been signed between PUFM and Dutch Welle Radio, Germany, according to which the students of radio broadcasting would be offered internship and training in Bonn Germany.

Now, PUFM 104.6 has become a place of producing quality producers and presenters and is serving as a human resource center for the commercial needs of the broadcasting market. Many trained producers and presenters of PUFM are now working in commercial radio station of the country and are contributing their experience and skills professionally.

Punjab University FM 104.6 has been divided into three departments:

1. Programming and transmission

2. New and Outdoor Current Affairs

3. Admin Department

\subsection{FM 96.6 Voice of LCWU}

FM 96.6 is the first educational radio station in Pakistan at a women's university. . It is situated in the premises of Lahore College for Women University. Voice of LCWU 96.6, a non- commercial radio channel, has been established with the prime objective of disseminating educational information and to provide a practice area for media students of university. Recorded test transmission was aired on 23 March 2009 by Ayesha Saba, a student of Mass Communication and initially its duration was one hour but in 2010 on $4^{\text {th }}$ January it started its regular 2 hour daily transmission from 11 am to $1 \mathrm{pm}$. After this, the time of transmission increased on November 2010 which was from $11 \mathrm{am}$ to $2 \mathrm{pm}$. The producers and presenters are Mass Communication students which are trained to become presenters/ radio producer and are encouraged to enhance their vocal quality for voice over's for radio documentaries and features.

One of the prime objectives of Voice of LCWU 96.6 is to provide a learning platform to the students of Communication Studies and to provide professional training. Students doing specialization in broadcast media practice their knowledge of practical journalism in a real encouraging radio broadcasting atmosphere.

\subsection{Radio Kinnaird FM 97.6}

Radio Kinnaird FM 94.6 is basically a non-commercial radio channel which has been established to provide technical training facilities to the students and to provide educational services to the people of Lahore City. Students doing specialization in electronic are offered to practice their knowledge and skills in order to make them suitable for practical journalism and Radio broadcasting atmosphere. Kinnaird college FM radio 94.6 radio station is equipped with latest and modern broadcasting facilities. The radio station was established in February, 2011. The test transmission of 6 months was carried out before the inauguration of the radio station. Mr. Ahmed Noor, a well-known journalist of the time, is charge of this radio station. The time duration of its transmission is 2 hours daily which is still recorded and there is no specific time duration of its transmission. 


\section{Methodology}

The present research used survey method for the collection of data and for this purpose questionnaire tool was adopted. Universe of the present study is educational radios of Lahore and sample size consisted of three radios, PUFM 104.6, Voice of LCWU 96.6 \& Radio Kinnaird FM 97.6.

3.1. Technical Introduction of PUFM 104.6

Name of University: University of Punjab

Channel Name: PU FM 104.6

Transmission Time: 12:00-04:00 PM
Frequency: $104.6 \mathrm{MHz}$

Transmitter Power: 50Watt

List of Technical Staff

\begin{tabular}{|c|c|}
\hline Name & Designation \\
\hline Abdul Rehman & Studio Engineer \\
\hline Ahmad Raza Ghuman & IT Supervisor \\
\hline Masood Khalid Malhi & Audio Editor \\
\hline
\end{tabular}

List of Equipments

\begin{tabular}{|c|l|c|c|}
\hline No. & \multicolumn{1}{|c|}{ Name of Equipment } & Quantity & Status \\
\hline 1. & Micro Phone & 6 & Active \\
\hline 2. & Audio Mixer & 2 & Active \\
\hline 3. & CD Player & 2 & Active \\
\hline 4. & Audio Cassette player & 2 & Active \\
\hline 5. & MD Player & 2 & Active \\
\hline 6. & Computer Systems( 1 Server, 1 Reco Machine) & 6 & Active \\
\hline 7. & Head Phone & 12 & 6 Active \\
\hline 8. & IC Recorder & 6 & 4 Active \\
\hline 9. & Sound Processor & 1 & Not Active \\
\hline 10. & Delaying Machine & 1 & Active \\
\hline 11. & Hybrid Set (For live calls) & 1 & Active \\
\hline 12. & Sound Speakers & 3 Pairs & 2 Active \\
\hline 13. & Radio Monitors & 12 & 4 Active \\
\hline 14. & FM transmitter (1 for Back up) & 2 & Active \\
\hline 15. & Software CDS & 25 & Active \\
\hline 16. & OB Microphones & 6 & 4 Active \\
\hline 17. & OB Kits & 2 & 0 Active \\
\hline
\end{tabular}

Table given above gives us a detailed introduction of technical standing of PUFM 104.6. It includes a team of three dedicated staff members which are available for the guidance of students. The transmission time is suitable for almost all students belonging to morning and evening programs. All equipment, other than OB kits, is in well working condition.

\subsection{Technical Introduction of Radio Kinnaird FM 97.6}

Name of University: Kinnaird College for Women

Channel Name: Radio Kinnaird

Frequency: $97.6 \mathrm{MHz}$

Transmission Time: 11:00 AM- 01:00 PM Transmitter Power: 230 Watts

List of Technical Staff

\begin{tabular}{|c|c|}
\hline Name & Designation \\
\hline Syed Majid Ali & Broadcast Engineer \\
\hline
\end{tabular}

List of Equipments

\begin{tabular}{|r|l|c|c|}
\hline \multicolumn{1}{|c|}{ No. Name of Equipment } & Quantity & Status \\
\hline 1. & Micro Phone & 5 & Active \\
\hline 2. & Audio Mixer & 2 & Active \\
\hline 3. & CD Player & Not Available & N/A \\
\hline 4. & Audio Cassette player & Not Available & N/A \\
\hline 5. & MD Player & Not Available & N/A \\
\hline 6. & Computer Systems( 1 Server, 1 Reco Machine) & 10 & Active \\
\hline 7. & Head Phone & Not Available & N/A \\
\hline 8. & IC Recorder & Not Available & N/A \\
\hline 9. & Sound Processor & Not Available & N/A \\
\hline 10. & Delaying Machine & 1 & Active \\
\hline 11. & Hybrid Set (For live calls) & Not Available & N/A \\
\hline 12. & Sound Speakers & 4 & Active \\
\hline 13. & Radio Monitors & Not Available & N/A \\
\hline
\end{tabular}


On Campus Technical Training facilities in Media Schools of Lahore.

\begin{tabular}{|c|c|c|c|}
\hline 14. & FM transmitter & 1 & Active \\
\hline 15. & Software CDS & Not Available & N/A \\
\hline 16. & OB Microphones & Not Available & N/A \\
\hline 17. & OB Kits & Not Available & N/A \\
\hline
\end{tabular}

Table showing figures for technical facilities of Radio Kinnaird includes most columns showing not available result. Most of the equipment required for the training of students is missing. However, it provides a starting point or point of departure for the female students of Lahore College for Woman University.

3.3. Technical Introduction of Voice of LCWU FM 96.6

Name of University: Lahore College for Women University

Channel Name: Voice of LCWU FM 96.6

Frequency: $96.6 \mathrm{MHz}$

Transmission Time: 11:00-01:00 PM

Transmitter Power: 500 Watts

List of Technical Staff

\begin{tabular}{|c|c|}
\hline Name & Designation \\
\hline Shoaib Yousaf & $\begin{array}{c}\text { FM operator, } \\
\text { Technical }\end{array}$ \\
\hline
\end{tabular}

List of Equipments

\begin{tabular}{|c|l|c|c|}
\hline No. & \multicolumn{1}{|c|}{ Name of Equipment } & Quantity & Status \\
\hline 1. & Micro Phone & 9 & Active \\
\hline 2. & Audio Mixer & 2 & Active \\
\hline 3. & CD Player & 1 & Active \\
\hline 4. & Audio Cassette player & 1 & Active \\
\hline 5. & MD Player & Not Available & N/A \\
\hline 6. & Computer Systems( 1 Server, 1 Reco Machine) & 4 & Active \\
\hline 7. & Head Phone & Not Available & N/A \\
\hline 8. & IC Recorder & Not Available & N/A \\
\hline 9. & Sound Processor & 1 & Active \\
\hline 10. & Delaying Machine & 1 & Active \\
\hline 11. & Hybrid Set (For live calls) & 2 & Active \\
\hline 12. & Sound Speakers & Not Available & N/A \\
\hline 13. & Radio Monitors & 1 & Active \\
\hline 14. & FM transmitter & Not Available & N/A \\
\hline 15. & Software CDS & Not Available & N/A \\
\hline 16. & OB Microphones & Not Available & N/A \\
\hline 17. & OB Kits & 1 & Active \\
\hline 18. & OB Van & & 1 \\
\hline
\end{tabular}

According to collected data for Lahore College for Women University radio voice of LCWU 96.6, only one person is available for the technical support of student. There is no fix time schedule for the transmission. On the other hand, it airs recorded transmission which does allow students to experience challenges of live transmission. Available equipments of the station are sufficient for the recorded transmission.

\subsection{Comparison Tables of Technical Facilities}

Number of Students Seeking Training

\begin{tabular}{|c|c|c|}
\hline Punjab University & Kinnaird College & $\begin{array}{c}\text { Lahore College for Woman } \\
\text { University }\end{array}$ \\
\hline 1000 & 500 & 250 \\
\hline
\end{tabular}

Transmitter Power

\begin{tabular}{|c|c|c|}
\hline Punjab University & Kinnaird College & Lahore College for Woman University \\
\hline 50 Watt & 500 Watt & 230 Watt \\
\hline
\end{tabular}

Transmission Time

\begin{tabular}{|c|c|c|}
\hline Punjab University & Kinnaird College & $\begin{array}{c}\text { Lahore College for Woman } \\
\text { University }\end{array}$ \\
\hline 12:0004:00PM & $11: 00 \mathrm{AM}-01: 00 \mathrm{PM}$ & 11:00AM-01:00PM \\
\hline
\end{tabular}

List of Technical Staff

\begin{tabular}{|c|c|c|}
\hline Punjab University & Kinnard College & Lahore College for Woman University \\
\hline Abdul Rehman & Syed Majid Ali & Shoaib Yousaf \\
\hline Ahmad Raza Ghuman & & \\
\hline Masood Khalid Malhi & & \\
\hline
\end{tabular}


List of Equipments

\begin{tabular}{|c|c|c|c|c|}
\hline No. & Name of Equipment & PU & KCW & LCWU \\
\hline 1. & Micro Phone & 6 & 5 & 9 \\
\hline 2. & Audio Mixer & 2 & 2 & 2 \\
\hline 3. & CD Player & 2 & Not Available & 1 \\
\hline 4. & Audio Cassette player & 2 & Not Available & 1 \\
\hline 5. & MD Player & 2 & Not Available & Not Available \\
\hline 6. & $\begin{array}{l}\text { Computer Systems (other than } 1 \text { Server, } 1 \\
\text { Reco Machine) }\end{array}$ & 6 & 10 & 4 \\
\hline 7. & Head Phone & 12 & Not Available & 6 \\
\hline 8. & IC Recorder & 6 & Not Available & Not Available \\
\hline 9. & Sound Processor & 1 & Not Available & Not Available \\
\hline 10. & Delaying Machine & 1 & 1 & 1 \\
\hline 11. & Hybrid Set (For live calls) & 1 & Not Available & 1 \\
\hline 12. & Sound Speakers & 3 Pairs & 4 & 2 \\
\hline 13. & Radio Monitors & 12 & Not Available & Not Available \\
\hline 14. & FM transmitter & 2 & 1 & 1 \\
\hline 15 . & Software CDS & 25 & Not Available & Not Available \\
\hline 16. & OB Microphones & 6 & Not Available & Not Available \\
\hline 17. & OB Kits & 2 & Not Available & Not Available \\
\hline 18. & OB Van & $\begin{array}{c}\text { Not } \\
\text { Available }\end{array}$ & Not Available & 1 \\
\hline
\end{tabular}

\section{Findings \& Interpretations}

The purpose of the present study is to compare the technical standing of FM radio stations of three prestigious institutions i.e. university of the Punjab, Lahore College for Women University and Kinnaird College. As mentioned in the chapter of methodology, survey method was applied on the present research and results are presented in table form for the purpose of better comparison.

On the basis of data collected above, the researcher found that PUFM 104.6 leads the rest two FM radio broadcasting houses in terms of its equipment, capacity for training the students, technical staff it has available for the training and operations of FM radio station and in terms of its transmission time. On the other hand, maintenance of already available equipment with no item in mal functioning condition shows professionalism of its staff and administration. Lahore College for Woman University gets second place as a media training house and practice laboratory for the students. Kinnaird College for Women falls last in the list for having no live transmission and due to its shorter time span for transmission.

\section{Conclusion}

In a country like Pakistan, where media had been the most controlled in practice and had been limited as an academic choice, above mentioned set ups are a step forward and positive step not only by adding another profession in list of already available options for young generation but also in making a real professional image of new born Pakistani media by producing young talented and well trained media professionals. On the basis of data collected above and its interpretation, following conclusions can be drawn;

> University of Punjab has comparatively more equipped practice area for its students in form of PUFM 104.6 as compared to Lahore College for Woman University and Kinnaird College for Women.

$>$ Overall, public sector universities in Lahore offer training to their student but do not have sufficient practice place and equipment for this purpose.

$>$ In the era of electronic media where it is believed to be the representative media of society, students are not offered variety of activities to in order to get mastery of it.

$>$ For total number of 1750 students, above mentioned radio labs, technical staff and transmission schedules are not sufficient by any means.

> Lack of equipment and malfunctioning of already available material shows that there is lack of particular check and balance on these media institution by higher authorities and higher education commission.

\section{Acknowledgements}

Allah blessed us with the strength to complete the research and bring it down in black and white. The contribution of Mr. Naveed Iqbal Chaudhry, Lecturer, Institute of communication studies in the form of knowledge of research which he imparted during our studies is the key factor in the construction of this paper. The motivation and guide lines of Mr. Fahad Anis, M.phil scholar at Allama Iqbal Open University, Islamabad worth acknowledging before I close the paper. May God bless them with success they deserve. 